\title{
Outsourcing for Sustainable Waste Disposal in Lagos Metropolis: Case Study of Agege Local Government, Lagos
}

\author{
Olalekan B. A Idowu (Corresponding Author) \\ Department of Estate Management, University of Lagos \\ Akoka, Nigeria \\ E-mail: obaidowu@yahoo.com
}

M. M. Omirin

Department of Estate Management, University of Lagos

Akoka, Nigeria

J. U. Osagie

Department of Estate Management, University of Lagos

Akoka, Nigeria

Received: September 27, 2011

Accepted: October 25, $2011 \quad$ Published: December 1, 2011

doi:10.5539/jsd.v4n6p116

URL: http://dx.doi.org/10.5539/jsd.v4n6p116

\begin{abstract}
The challenge posed by the population growth of Lagos emanates from the need to effectively manage the several tons of solid waste that are generated daily. The state Government has contracted the solid waste collection and disposal to the private sector operators with the hope that a clean Lagos can be sustained at no extra cost implication to the government. This study was undertaken to appraise the performance of the private sector participation (PSP) in the state using Agege Local Government as the case study. The study which is exploratory employed the use of questionnaires to elicit information from two sets of respondents, the residents and the private sector operators. Based on the findings, the scorecard as rated by the households gives the PSP operators a pass mark showing a wide acceptance of their service. Also, there is a need for the re-organisation of their accounting system with a view to ensuring proper accountability of all money paid as PSP dues. The PSP too deserve some assistance towards the improvement of the welfare of their workers to enhance staff commitment. Government should facilitate payment of participant fees. Commensurate punishment should be imposed on defaulters per default period and based on the amount. Finally, the Government should open up more and not too distant refuse dumps and landfills as well as increase the fees payable to the operators.
\end{abstract}

Keywords: Urbanisation, Governance, Outsourcing, Solid waste management, Private sector participation, Sustainability, Agege

\section{Introduction}

Sustainable Development concept is increasing in the last decades. Sustainability is aimed at meeting the needs of the present without compromising the future (Amado et al., 2007). The Commonwealth action for Human Settlements (ComHabitat, 2006) noted that one third of Commonwealth countries have urban growth rates of between 3 and $6 \%$. It listed Nigeria, Bangladesh and Pakistan among the countries with risk of climate change and environmental degradation. Lagos, as a result of her unique status as Nigeria's former administrative capital and presently the commercial capital of the nation, has been noted for rapid population growth over time. Consequently, it has suffered numerous negative effects of urbanisation such as slum formation, traffic congestion, poor housing, overcrowding, social menace of armed robbery and proliferation of social vices perpetrated by miscreants known as 'area boys' and 'omo-onile' syndrome, high waste generation but improper disposal of solid waste, flooding and decimated infrastructure which was hitherto inadequate etc. The volume of solid waste generation is one obvious consequence of rapid urbanisation (Ogu, 2000). This menace in Lagos reached a stage that it was becoming difficult to manage its collection and disposal. This was evident in 
the ubiquitous appearance of solid waste dumps creating unsightly scenes and the release of foul odour. The United Nations Committee of Housing Settlements (UNCHS) report (1996) cited in Ogu (2000) observed that between one third and one half of solid wastes in some developing countries were left uncollected. "The proportion of solid waste collected and disposed of is less than 25\% in Dar es Salaam (Tanzania) and about 40\% and $60 \%$ respectively for Karachi (Pakistan) and Jakarta (Indonesia).

In Lagos, prior to this time waste disposal effort was futile. Some residents were in the habit of indiscriminate dumping of refuse which littered virtually all open spaces in the city. According to Isu (2005) as cited by Kalu et al. (2009), 87\% of Nigerians used unsanitary methods of solid waste disposal which constitute an eyesore and a nuisance; produce unpleasant odour and create a breeding ground for pests and diseases. Things obviously have to be done differently in a mega city to be able to sustain the economic tempo of the mega city.

Proper waste management therefore is an important environmental issue that affects both the quality of lives of individuals as well as the outlook of a city. Problems of waste generation vary from city to city and from country to country, depending on the characteristics and culture of such cities and the social practices of the populace. Therefore, for any city, or country to adopt a sustainable waste management system, it has to be done looking at all the socio-cultural and political factors and belief system of the citizens.

Sustainable development according to Redclift (1992) is development that meets the needs of the present without compromising the ability of future generations to meet their own needs.

Lagos state in the past has had to battle with the problem of waste collection and disposal. Successive governments then tried to find a lasting solution to this menace without success.

Over the years different Governments have come out with its own waste management plans as part of the planning process. It began with direct waste collection by the local government from a central/designated point where people dumped refuse. During this waste management regime, residents were expected to take their refuse to the designated points. Sometimes, they used cart pushers who collected refuse for a fee. The next waste management regime saw the town council authorities positioning giant size trash collector bins at strategic points from which their trucks came weekly to remove and replace.

Consequently, LAWMA, an agency was created to tackle the cleaning of the highways within the metropolis. The goal was to reduce the losses caused by the environmental degradation and improve the aesthetics along major roads thus assisting the state to ensure its cleanliness amidst the problem associated with urbanisation. However, the activities of LAWMA were limited to high ways and commercial areas. The state also after initiating the monthly environmental sanitation exercise, has tried to sustain it as means of getting residents to do their bit in waste management. The most recent programme is the outsourcing of waste collection to the private sector which was christened private sector participation (PSP) scheme. In the past, there was a lack of a holistic assessment of the processes and causes of land degradation (Linger et al., 2004). Some of the policies adopted by the previous administrations can be said to be tailored toward killing the ringworm and not leprosy. Ineptitude, lack of will and corruption seemed to be the bane which impeded the success of government efforts towards solving the menace.

Municipal solid waste heaps dot several parts of major Nigerian cities such as Lagos, Ibadan, Enugu, Kaduna, Aba, Port-Harcourt, Owerri and Warri blocking roads and creating several disposal problems. (United Nation's report, 2002).

Solid waste management is traditionally the responsibility of the local Council. However, the task appeared to be enormous for the local Government because of the amount of money involved thus necessitating the intervention of the state Government (Longe et al., 2009). Waste collection activities are the most expensive in waste management systems and its efficiency would have immediate impact on the level of municipal solid waste management (Zaini \& Gerrard, 2000; Zaini et al., 2002) cited in Zaini (2011). Currently, the Lagos state government is into pact with the private sector in waste collection and disposal. To ensure sustainable urban development the need for efficient solid waste management is inevitable.

The problem posed by improper management of waste in the past led to a situation in which most neighbourhoods in Lagos were littered with waste and the environment tainted. Consequently, the state has now intervened with a view to improving waste collection and disposal through its partnership with the private sector in a joint venture. It is therefore expected that the result will be a clean environment, efficient waste collection and quality service.

The specific objectives of this paper are to

- $\quad$ To determine the modalities adopted for outsourcing solid waste disposal in Lagos. 
- $\quad$ To determine the extent to which outsourcing and use of PSPs have improved solid waste disposal in Lagos.

- $\quad$ To determine the extent to which PSP has contributed to the improvement of environmental quality of Lagos metropolis.

- $\quad$ To identify the challenges faced by the PSP operators in the course of their duties in the metropolis.

\subsection{Hypothesis}

$\mathbf{H}_{\mathbf{O}}$ There is no significant change in the environmental quality of Lagos metropolis despite the introduction of Private Sector Participation in the solid waste collection.

\subsection{Scope of the Study}

The study is limited to Agege Local Government Area of the metropolis. Residential properties were examined with few cottage industries that were found in the case study as well as sparse commercial activities. This is because the study mainly focuses on waste generated by household and also because the PSPs are not expected to dispose industrial wastes from the contract agreement. The study is limited to solid waste collection and does not cover total waste management.

\subsection{Operational Definition of Terms}

Urbanisation is defined as the shift from a rural to an urban society and involves an increase in the number of people in urban areas during a particular year. Urbanisation is the process by which there is an increase in the proportion of people living in an urban area.

According to Lagos State Waste Management Authority (LAWMA), wastes include vegetable matter, paper, textiles, metal plastics, miscellaneous items, tyres etc. Thus, in this study household wastes include food remnants, used clothes and other materials which households consider useless and therefore dispose of.

Municipal Solid Waste- This is defined as non- air and sewage emissions which include household garbage, commercial refuse, construction and demolition debris, dead animals and abandoned vehicles. It also consists of vegetable matter, plastics, metals, textiles, rubber and glass (Cointreau, 1982; USEPA 2003) as contained in Walling et al. (2004).

PSP refers to Private Sector Participators. They are simply contractors who collect waste directly from the various houses. They all registered their organisations with LAWMA.

Outsourcing in this study is the giving out of waste collection contract to the private operators who are to collect it on behalf of the state in return for payment by the Lagos state Government.

Households are the residents who reside in the study area and were sampled for the questionnaires survey used to elicit data on waste collection by PSPs in the neighbourhoods.

\section{Literature Review}

Urbanisation in Nigeria is caused by high population growth and rural urban migration with serious environmental growth (Omofonwan \& Osa-Edoh, 2008). Urbanisation is accompanied by several environmental challenges which are the effects of so many factors including improper disposal of wastes. It does not only have negative effects it also has positive effects. Existing literature has revealed that urbanisation had positive effects on the quality of life in many societies except in Africa where it tends to have been undermined by the accomplished or political gains. Between 1950 and 2000 the developed countries had below 2\% urban growth rate. The case of developing countries was different. Nigeria and Bangladesh had the highest growth rate of 5.9\% and 5.6\% respectively. (United Nation's report, 2001). The population of Lagos state alone is put at 9,013,534 out of 140,000,000 (National Population, 2006). This gives an approximate figure of $6.4 \%$ of the Nigerian population. Urban population worldwide is considered as the factor responsible for the unprecedented rate of urban sprawl (Ujoh et al., 2010). Necessary caution should be exercised to prevent Lagos from this menace. For this to be realised there should be proper management of all the basic infrastructures and other facets of the city. Presently, the city has outsourced its waste collection to the private sector. Unrelenting urbanisation and largely unimpressive performance of the public sector in the provision of infrastructure in many cities resulted in the alternative strategies for urban environmental services (Ogu, 2000). It is clear that the private sector has been thriving in several areas due to its desire to attain optimum returns. Bearing this in mind some schools of thought have canvassed for public private partnership generally in Nigeria. It was believed that private sector participation would provide the much needed capital for investment in Infrastructure (World Bank, 1994) as contained in (Ogu, 2000). 
The contracting of waste disposal to private sector is outsourcing. The term outsourcing itself has been described in different ways by different people and scholars. However, the various definitions express the same thing in different words. It is the provision of a bundle or a full range of services by a single contractor while the facilities staffs are responsible only for managing the contractor relationship and monitoring its performance (Cotts, 1998). The main thing here is that the provision of the service is divorced from the company staffs that are to oversee the activities of the service provider. This allows for checks and balances. Relating this to waste management in Lagos state, the PSP operators are the contractors while the government staffs are to supervise them. Since the operators collect money for the job they are both responsible to the residents who generate the wastes and the Government. There should be a mid- point where the parties are to assess the operations of the PSP.

Outsourcing is not limited to a particular sector but covers a whole spectrum of human endeavour. There are different opportunities for outsourcing (Jones, 2009; Jayatilaka \& Hirscheim, 2009). Outsourcing has taken international dimensions (Hameri \& Tunkel, 2009). Companies are now leaving their shores for other countries to seek best performance with a view to ensuring best quality at a cheaper cost. Yik \& Joseph (2005) noted that recent economic trends have triggered outsourcing of building services operations in Hong-kong. Some schools of thought feel outsourcing is desired to reduce cost (Blender, 1999). To some, outsourcing enhances value (Elmuti, 2004). However, there are challenges which companies face and these have reduced their ability to have optimum returns (Carter, 2006). From literature, it can be deduced that outsourcing is not necessarily for cost reduction.

Management of public services often requires separation of core activities from key support services (Wallace, 2004). Government is to be responsible for governance and as such should not be distracted with unnecessary activities such as waste management. It is in this regard that the public private partnership is now in vogue in Nigeria. Padovani \& Young (2006) see outsourcing as a strategy used by many municipalities to provide high quality service at a low cost. They identified wide varieties of outsourcing initiatives of legal services, trash collection, health care, street cleaning etc. What actually requires an answer is whether indeed outsourcing of these services resulted in high quality and reduced cost. Padovani et al. (2006) suggested three key areas to assess service provider's performance. These include citizen's sensitivity, supplier market and switching costs. It also addresses the three parties to waste collection and disposal. These are the Government, the people who generate the waste and the PSP operators who collect the waste.

Waste management is no longer simply to be left to anyone but requires passion, professional training and technical know-how (Kalu et al., 2009). Efficient solid waste collection is a necessary ingredient towards an integrated waste management. Sustainable waste management must begin with solid waste collection. It cannot be left in the hands of unlearned and miscreants if the state will be saved the problem of diseases and noxious gases. The handling of the materials, their separation and recycling can fetch the state substantial revenue and enhance the transition of the state towards its metamorphosis into a planned mega city.

\section{Research methods}

\subsection{Overview of Study Area}

Lagos is one of the mega cities in Africa which is located in South Western Nigeria on the west coast of Africa, within latitudes $6^{\circ} 23^{\prime} \mathrm{N}$ and $6^{\circ} 41^{\prime} \mathrm{N}$ and longitudes $2^{\circ} 42^{\prime} \mathrm{E}$ and $3^{\circ} 42^{\prime} \mathrm{E}$. Although Lagos state is the smallest state in Nigeria, with an area of 356,861 hectares of which 75,755 hectares are wetlands, yet it has the second highest population, which is over $5 \%$ of the national estimate. However, a parallel population count by the Lagos State government put the population at about 17 million, the state's population according to the 2006 census was $9,013,534$ out of a national estimate of 140 million (National Population Commission, 2007). Of this population, metropolitan Lagos, an area covering $37 \%$ of the land area of Lagos State is home to over $85 \%$ of the state's population. The rate of population growth is about 275,000 persons per annum with a population density of 2,594 persons per square $\mathrm{km}$. In a United Nation's study of 1999, the city of Lagos was expected to hit the 24.5 million population mark by the year 2015 and thus be among the ten most populous cities in the world (Lagos State Government, 2006).

Lagos' share of Nigeria's GDP is 12\% valued at USD 29 Billion from USD 18 Billion in 2005. It has 80\% of country's industrial / commercial activities, $45 \%$ of national electricity consumption and $50 \%$ of petroleum products consumption (Lagos State Vision 20:2020 First Implementation 2010-2013).

Agege local government was adopted as the study area due to the ubiquitous presence of PSP operators and the heavy generation of waste in the area because of its dense population. One of the major features of a densely populated area is the high level of waste generation due largely to income level, education and awareness level. 
Within Agege Local Government are Local Council Development Areas making Agege one of the biggest and most populated LGA in Lagos.

Agege Local Government is one of the 20 constitutionally recognised Local Governments of Lagos in Nigeria. It has a population of 461,743 comprising of 238, 456 males and 23,287 females (2006 national census). These figures however differ from the one reported by the state itself representing 1,033,064 i.e. 564,239 and 468,825 male and female respectively (Oni, 2010). The study agrees with the latter figure which he noted appears to be more realistic.

\subsection{Data Collection Instrument}

The study is basically exploratory. The primary data were gathered using structured questionnaire to elicit information from the identified respondents in the study area. The researcher ensured that each surveyed property is administered with a questionnaire. Also personal interviews were conducted. Generally, two sets of questionnaires were used. One was administered to the PSP operators while the other was served on the residents of the study area. To determine the performance of the activities of PSP operators, a sample of 250 respondents were served questionnaires across the local government area of which 160 were analysed after collation and sorting. There were only 5 PSP operators in the area of study at the time of investigation, this was adopted. For secondary information relevant journals and internet materials were used.

\section{Results}

The data collected were analyzed and the results presented in this section. Various descriptive statistics were employed to elicit views from the two groups of respondents. These include frequency distribution and mean scores, aided with bar and pie charts. This section begins with the presentation of analyzed data on households followed by that of PSP operators.

The pie chart shown above provides a summary on the personal characteristics of the residents based on the information obtained from the questionnaires on their educational qualifications, types of accommodation, number of household members and the number of years spent in the neighbourhood. Data on education shows that there are 80 respondents representing $53.7 \%$ i.e. a little above average are Bachelor's degree holders. Next group is $46(30 \%)$ representing those who have SSCE, NCE, ND, and HND while $22(14.8 \%)$ and $1(0.7 \%)$ were M.Sc and M.Phil/PhD holders respectively.

As regards the type of accommodation, residential house is the most common type. From 157 responses obtained, 124 indicates residential types of accommodation; 26, commercial; 5, industrial; 2, others. This shows that the study area is largely a residential area, constituting residents with the likelihood of generating and disposing waste.

Household size differs from one household to another. While we have households with 1 member, there are some others with 12 members. From the responses gathered, table 1 was obtained, showing only 45 responses on household size. There are few numbers of respondents with 11 and 12 members.

In table 2 below, a total of 158 responses were obtained on period of stay in the neighbourhood. From this figure, 61 had spent periods of between 1 and 5 years, 51, between 6 and 10 years while 46 are more than 10 years. The distribution gives a cumulative of $61.4 \%$ of the entire households who lived in the neighbourhood for period up to 6 years and above. This indicates more than half of the population in the areas had been living in the neighbourhood for, at least 6 years ago.

How the household in the study area disposed their waste in time past and at present are shown in table 3, with a corresponding number (and their proportion) of households. There were many who in the past used cart pushers as well as LAWMA. When put together, $93.7 \%$ of the respondents used cart pushers and LAWMA in the past. More than half of this figure alone used cart pushers. There are few others who used public dumping grounds. On the other hand, in the recent time, the households have resorted to using PSP. It was gathered that $90.4 \%$ of the household now used PSP. Only few (5.1\%) still use cart pusher while none of the household used LAWMA anymore. In short, it can be deduced that PSP operation has been accepted by the people for waste disposal.

Common household waste constitutes a larger proportion of what is generated as refuse. Commercial and industrial waste is very minimal. The figure above presents various types of waste produced in the study location.

In table 4, four measures used to gauge household level of awareness are shown with the number of respondents and their proportion for each of the two responses supplied. It was discovered that $97.5 \%$ of the households knew about the operation of PSP in the area, only $44.9 \%$ of the households knew the name of their PSP operators 
while $45.8 \%$ knew where their offices are located. Also, the response of the residents on whether the waste service provider should be retained showed a positive response of $151(98.1 \%)$ as against $3(1.9 \%)$ people who wanted that their service be discarded.

Households responded to how frequently their waste was collected. The outcome of their response (Table 5) shows that most of the waste was collected once in a week. Not less than $80 \%$ of the household waste can be said to be collected once in a week. The remaining $20 \%$ of the household waste was collected in the following way; $2.1 \%$ in every two weeks, $10.7 \%$ every month and $7.1 \%$ varied from time to time.

The households rated the performance of PSP operators very high. In hierarchical order, the performance indicators are given in table 6 as rated by the households. The analysis shows that not less than $70 \%$ of the households agreed/strongly agreed with the first eight indicators in the table rated on a scale of 1 to 5 , they all fall on the scale number 4 which stands for 'agree'. In this respect, the households agreed to the following, that introduction of PSP has brought environmental improvement in the area; that there is proper record of refuse charge; that legal framework establishing PSP is adequate; that quality of service provided is excellent; that supervision of PSP operators is adequate; that attitude of PSP workers is cordial; that ubiquitous refuse heaps all over Lagos has now disappeared.

The last three indicators in the tables were the negatively worded performance indicators which the households quite disagreed with or in another words, gained little support from the households. The indication as shown from this analysis is that the households relegated facts about the PSP operation; that PSP operators use environmentally friendly vehicle-open/uncovered vehicle; that PSP vehicle is too old and breaks down constantly; that cost of waste disposal charged by the PSP is too high.

\subsection{Descriptive Analysis of PSP Operators Response/Date of Incorporation}

There are five PSP operators operating in the location of study having their offices located within the same area. However, the period of their incorporation differs from one to another. While two operators had been incorporated before 2000 others came thereafter. Cosmopolitan Environmental Service and Praise Multiventure Ltd. were incorporated the same year i.e. 1995 followed by Letok Cleaning and Waste Management Company in 2006. The other two, Team 5 Stars Environmental Partners and Akins-John Environmental Services were incorporated in 2007 and 2010 respectively.

The result of the interview schedule conducted to elicit information on the assessment of PSP operation by the operators shows that all the PSP operators have been in business for periods not less than 10 years. While 4 out of 5 have members of staff that are more than 10, in number, 1 has between $6-10$. The turnover rate of the staff is high among 3 operators but low for the 2 remaining ones. In their operation they all engaged purposed designed waste vehicle. For 4 operators, those vehicles were financed and acquired through bank loans. The fifth operators used personal funds and funds from relations.

Four of the operators collected waste once every week while the remaining 1 did it on clients' demand. The mode of charges for these wastes was in two categories; per house and per householder. Two operators charged per householder while the other three charged per house. Wastes collected were not separated, it was however disposed in government designated dump areas.

The operators all agreed on some factors affecting their performance. Generally, these include delay in payment of fees, inadequate enforcement for defaulters, irregular payment by the people and low pay for the services by government. While the five operators strongly agreed on the first two factors; they shared between agreed and strongly agreed for the last two. Three operators, from five, agreed to the fact that there was irregular payment by the people and the remaining two strongly agreed on it. On the other hand, one, from four, agreed that money paid for the service by government was too low, the other three strongly agreed to that fact. Also, 4 operators disagreed to the fact that there was corruption on the part of government official, 1 maintained strongly agreed position. All the operators debunked the statement that people were unwilling to use PSP. But while four operators disagreed that the PSP was forced on the people, one agreed to the contrary.

Lack of adequate facilities was indicated by the operators as not being a factor affecting operation; one strongly disagreed that PSP operators lack adequate facilities, the other remaining four just disagreed to the fact. Three of the five operators, who responded on the distance of designated refuse dumps strongly, agreed that the dumps site is too far. The remaining two operators were undecided on this issue. It is gathered that on the level of awareness of the PSP programme, a total of 4 operators agreed that the programme is well publicised while one disagreed. 


\subsection{Hypothesis}

$\mathbf{H}_{\mathbf{O}}$ There is no significant change in the environmental quality of Lagos metropolis despite the introduction of Private Sector Participation in the solid waste collection.

\subsection{Descriptive Statistics From Analysis of Variance and One Way Analysis of Variance for Significant Difference in possible Influence}

From what is shown above, a significant contribution of PSP to the environmental quality of Lagos state is found; $\mathrm{p}<0.005$. The result indicates that there is significant difference in contribution made by PSP, $\mathrm{M}=4.19$, $\mathrm{SD}=0.613$, from other like cart pusher, $\mathrm{M}=3.44, \mathrm{SD}=0.859$ and $\mathrm{Both}, \mathrm{M}=3.56, \mathrm{SD}=0.667$ (see appendix). Hence, the null hypothesis that there is no significant contribution of PSP to the environmental quality of Lagos metropolis' is rejected while the alternative hypothesis is supported.

Post hoc test is carried out to investigate where the difference occurs among the method, that is, which method is different from the others in terms of environmental quality. The outcome of the test is shown in table below.

This reveals that the difference in environmental performance of waste collection methods exist between, Cart pusher and PSP; MD $=-0.754, p<0.01$, and between PSP and Both (using both cart pusher and PSP); MD = $-0.636, p<0.05$. It invariably implies that no significant difference between Cart pusher and Both; $M D=-0.118$, $\mathrm{p}>0.05$, in terms of environmental performance.

\section{Conclusion/ Recommendations}

Proper waste management is an important environmental issue that is of concern worldwide due to its effect on the quality of lives of city dwellers cum the outlook of an urban city. Due to the status of Lagos as a commercial capital of Nigeria and its twin position as an emerging most populous mega city in Africa, it is imperative that its cleanliness must not be handled with levity. In line with this, the Lagos state Government sometime came up with a bill to establish the Lagos Waste Management Authority. The agency was saddled with all issues relating to waste collection and waste management. It is as a result of the challenge associated with waste collection in the state that the issue of public private partnership emerged. Thus, this study is embarked upon to reveal the activities of the private sector in Agege Local Government, one of its densely populated local Governments in order to harness the full benefits of private participation.

Generally, the study revealed that the performance of the private sector participants in waste collection was not as appalling as expected. In short, the resultant scorecard shows that they earned a pass mark. Almost all the parameters such as frequency of waste collection, legal framework, quality of service, adequacy of supervision, attitude of PSP workers and disappearance of past ubiquitous refuse heaps received favourable rating. This has raised some fundamental issues on the position of some scholars of the need by the Government to leverage on the advantage of PPP. However, there were allegations by householders that money paid by them to the Government for waste collection services was not credited in their favour. There is a need for the re-organisation of the accounts department which is responsible for the collection of the PSP dues.

On the other hand, the private operators themselves have to look inward to reduce or eliminate the cause of their higher staff turnover as this may in the long run affect the quality of their final output which may in turn have negative effect on the environment. Staff welfare in terms of better salaries and other emoluments should be looked into in order to enhance staff commitment towards waste collection.

While the private sectors operators appear to discharge their contractual role, it is the Government that needs to address some issues raised by operators on the delayed payment of their fees, opening of more and not too distant refuse dumps/ landfills, improved fees for the services rendered by the waste service providers.

In the light of the above, we recommend that the Government should ensure prompt payment of participant fees. This will encourage better commitment on their part and ensure improvement in the quality of service rendered by them while ensuring cleaner environment. Also, commensurate punishment should be imposed on defaulters by the authority scheduled with enforcing the waste management law. What this suggests is that there must be proper record to ascertain which householder is indeed in default as well as the time and the exact amount.

Finally, the Government should provide the enabling environment for the private sector to operate as well as the legal framework while the PSPs provide the logistics.

\section{References}

Abrantes, V., Pinto, C. \& Peixoto, M. (2011). Construction sustainability progress in Portugal. XXXV IAHS World congress on Housing Science- Melbourne. 
Adedeji, O. H. \& Ademiluyi, I. K. (2009). Urban agriculture and urban land use planning: Need for a synthesis in metropolitan Lagos, Nigeria. Journal of Geography and Regional Planning. 2 (3), 43-50.

Amado, M. P., Rebeiro, M. R., Pinto, A. J. \& Santo, C. V. (2007). Operative process in sustainable urban planning. XXXV IAHS Congress on Housing Science - Melbourne.

Andrew, C. (2006). The positive effect of FM solutions on achieving corporate values. Retrieved from www.occupiers.org.

Commonwealth action for human settlements. (ComHabitat) (2006). Urbanisation, growing slums and global change: A challenge Commonwealth countries need to address urgently. Briefing paper produced for the Commonwealth Civil Society Consultation, Marlborough House, London, Wednesday $15^{\text {th }}$ November, 2006.

Cotts, D. G. (1998). The facility management handbook. New York: American Management Association.

Elmulti, D. (2004). The perceived impact of outsourcing on organisational performance. Mid American Journal of Business. 18 (2), 33-42. http://dx.doi.org/10.1108/19355181200300010

Hameri, A . \& Tunkelo, T. (2009). Capital outsourcing- a way to move complex products to emerging markets. Strategic Outsourcing. 2 (1), 54-67. http://dx.doi.org/10.1108/17538290910935891

Jayatilaka, B. \& Hirschheim, R. (2009). Changes in IT sourcing arrangements: An interpretive field study of technical and institutional influences. Strategic Outsourcing. 2 (2), 84-122. http://dx.doi.org/10.1108/17538290910973349

Jones, W. O. (2009). Outsourcing in China: opportunities, challenges and lessons learned. Strategic Outsourcing. 2 (2), 187-203. http://dx.doi.org/10.1108/17538290910973385

Kalu, C., Modugu, W. W. \& Ubochi, I (2009). Evaluation of solid waste management policy in Benin metropolis. Edo state Nigeria. African Scientist. 10 (1), 1-7.

Liniger, H. P., Douglas, M. \& Schwilch, G. (2004). Towards sustainable land management 'common sense' and some other key missing elements (The WOCAT) Experience ISCO 2004- 13 International Soil Conservation Organisation Conference Brisbane July 2004- Conserving Soil and Water for Society: Sharing Solutions.

Longe, E. O., Longe, O. O. \& Ukpebor, E. F. (2009) . People's perception on household solid waste management in Ojo local Government area. Iran Journal of Environmental Health SC. Eng. 6 (3), 209-216.

Ogu, V. I. (2000). Private sector participation and municipal waste in Benin City, Nigeria. Environment and Urbanisation. 12 (2), 103-117. http://dx.doi.org/10.1177/095624780001200209

Omofonmwan, S. I. \& Osa-Edoh, G. I. (2008). The challenges of environmental problems in Nigeria. Journal of Human Ecology. 23 (1), 53-57.

Potsiou, C. \& Doytsher, Y. (2010). Urban management: Availability of technical tools. International Conference SDI 2010- Skopje, 15-17.

Redclift, M. (1992). The meaning of sustainable development. Geoforum. 23 (3), 395 - 403. http://dx.doi.org/10.1177/095624780001200209

Ujoh, F., Kwabe, I. D. \& Ifatimehin, O. O. (2010). Understanding urban sprawl in the federal capital city, Abuja: Towards sustainable urbanisation in Nigeria. Journal of Geography and Regional Planning. 3 (5), 106-113.

United Nations Johannesburg Summit. (2002). Nigerian country profile- CP 2002 Nigeria, 1-77.

United Nation's Report (2001). Urbanisation patterns and rural population growth at the country level. United Nations Population Division. World Population Prospect. The 2001 Revision.

Wallace, D. (2000). Facilities management: Improving the management of support services in higher education. Scottish higher education funding. 1-58.

Walling, E., Walston, A., Warren, E., Warshay, B. \& Wilhelm, E. (2004). Municipal solid waste management in developing countries, Nigeria, a case study, Group 9, NTRES, 314

Yik, F. H. W. \& Lai, H. K. (2005). The trend of outsourcing for building services operation abd maintenance in Hong Kong. Facilities. 23 (1/2), 63-72. http://dx.doi.org/10.1108/02632770510575901

Zaini, S. (2011). Municipal solid waste management in Malaysia. Journal of Applied Sciences in Environmental Sanitation. 6 (1), 29-38. 
Table 1. Household size

\begin{tabular}{ccc}
\hline Household Size & Frequency & $\%$ \\
\hline 1 & 4 & 2.5 \\
2 & 5 & 3.1 \\
3 & 1 & 0.6 \\
4 & 7 & 4.4 \\
5 & 6 & 3.8 \\
6 & 9 & 5.6 \\
7 & 5 & 3.1 \\
8 & 5 & 3.1 \\
11 & 1 & 0.6 \\
12 & 2 & 1.3 \\
Total & 45 & 100 \\
\hline
\end{tabular}

Source: Field survey 2011.

Table 2. Distribution of respondents' duration of stay

\begin{tabular}{ccc}
\hline Length of Stay & Frequency & $\%$ \\
\hline 1-5years & 61 & 38.6 \\
6-10years & 51 & 32.3 \\
Above 10years & 46 & 29.1 \\
Total & 158 & 100 \\
\hline
\end{tabular}

Source: Field survey $\overline{2011 .}$

Table 3. Method of waste disposal

\begin{tabular}{ccc}
\hline Waste Collector & In the Past & At present \\
\hline Cart pusher & $84(53.2)$ & $8(5.1)$ \\
LAWMA & $64(40.5)$ & - \\
PSP & - & $142(90.4)$ \\
Government & $2(1.3)$ & - \\
Cart pusher/PSP & - & $6(3.8)$ \\
Public dumping ground & $6(3.8)$ & - \\
Others & $2(1.3)$ & $1(0.6)$
\end{tabular}

Source: Field survey 2011.

The figure below presents various types of waste produced in the study location.

Table 4. Household level of awareness of PSP operation

\begin{tabular}{cccc}
\hline Level of awareness & YES & NO & Total \\
\hline Are you aware of PSP operation in your area & $153(97.5)$ & $4(2.5)$ & 157 \\
Do you know the name of your PSP waste operator & $70(44.9)$ & $86(55.1)$ & 156 \\
Do you know their office address & $71(45.8)$ & $84(54.2)$ & 155 \\
$\begin{array}{c}\text { Do you support that the service of the PSP waste } \\
\text { service provider be retained }\end{array}$ & $151(98.1)$ & $3(1.9)$ & 154 \\
\hline
\end{tabular}

Source: Field survey 2011. 
Table 5. How often the waste was collected

\begin{tabular}{ccc}
\hline Period & Frequency & $\%$ \\
\hline Once a week & 112 & 80 \\
Fortnightly & 3 & 2.1 \\
Monthly & 15 & 10.7 \\
Others & 10 & 7.1 \\
Total & 140 & 100 \\
\hline
\end{tabular}

Source: Field survey 2011.

Table 6. Respondents' rating of PSP operators' performance

\begin{tabular}{|c|c|c|c|c|c|c|c|}
\hline Performance Indicators & $\mathrm{SD}$ & $\mathrm{D}$ & $\mathrm{U}$ & $\mathrm{A}$ & $\mathrm{SA}$ & $\begin{array}{c}\text { Mean } \\
\text { score }\end{array}$ & RANK \\
\hline $\begin{array}{c}\text { Introduction of PSP has brought } \\
\text { environmental improvement in } \\
\text { the area }\end{array}$ & $2(1.3)$ & $8(5.2)$ & $4(2.6)$ & $62(40)$ & $79(51)$ & 4.34 & 1 \\
\hline $\begin{array}{c}\text { There is proper record of refuse } \\
\text { charge }\end{array}$ & $2(1.3)$ & $11(7.1)$ & $15(9.7)$ & $39(25.3)$ & $87(56.5)$ & 4.29 & 2 \\
\hline $\begin{array}{c}\text { Legal framework establishing } \\
\text { PSP is adequate }\end{array}$ & - & $4(2.6)$ & $20(13.1)$ & $63(41.2)$ & $66(43.1)$ & 4.25 & 3 \\
\hline $\begin{array}{c}\text { Quality of service provided is } \\
\text { excellent }\end{array}$ & $3(2)$ & $10(6.5)$ & $8(5.2)$ & $74(48.4)$ & $58(37.9)$ & 4.14 & 4 \\
\hline $\begin{array}{c}\text { Supervision of PSP operators is } \\
\text { adequate }\end{array}$ & $1(0.7)$ & $14(9.3)$ & $18(11.9)$ & $54(35.8)$ & $64(42.4)$ & 4.10 & 5 \\
\hline $\begin{array}{c}\text { Number of time refuse is } \\
\text { collected is adequate }\end{array}$ & $2(1.3)$ & $25(16.2)$ & $6(3.9)$ & $45(29.2)$ & $76(49.4)$ & 4.09 & 6 \\
\hline $\begin{array}{c}\text { Attitude of PSP workers is } \\
\text { cordial }\end{array}$ & $5(3.2)$ & $14(9.1)$ & $24(15.6)$ & $71(46.1)$ & $40(26)$ & 3.82 & 7 \\
\hline $\begin{array}{c}\text { Ubiquitous refuse heaps all over } \\
\text { Lagos has now disappeared }\end{array}$ & $9(6.2)$ & $13(8.9)$ & $18(12.3)$ & $76(52.1)$ & $30(20.5)$ & 3.72 & 8 \\
\hline $\begin{array}{c}\text { PSP operators use } \\
\text { environmentally friendly } \\
\text { vehicle-open/uncovered vehicle }\end{array}$ & $12(7.8)$ & $39(25.3)$ & $44(28.6)$ & $23(14.9)$ & $36(23.4)$ & 3.21 & 9 \\
\hline $\begin{array}{c}\text { PSP vehicle is too old and breaks } \\
\text { down constantly }\end{array}$ & $11(7.3)$ & $34(22.7)$ & $50(33.3)$ & $43(28.7)$ & $12(8.0)$ & 3.07 & 10 \\
\hline $\begin{array}{c}\text { Cost of waste disposal charged } \\
\text { by the PSP is too } \\
\text { High }\end{array}$ & $57(37)$ & $25(16.2)$ & $7(4.5)$ & $31(20.1)$ & $34(22.1)$ & 2.74 & 11 \\
\hline $\begin{array}{c}\text { Source Feld survey } 2011 \\
\text { (n) }\end{array}$ & & & & & \\
\hline
\end{tabular}

Source: Field survey 2011. 
Table 7a. Descriptive statistics from analysis of variance

\begin{tabular}{ccccc}
\hline & $\mathrm{N}$ & Mean & Std. Deviation & Std. Error \\
\hline Cart pusher & 8 & 3.438 & 0.859 & 0.304 \\
PSP & 139 & 4.192 & 0.613 & 0.052 \\
Both & 6 & 3.556 & 0.929 & 0.379 \\
Total & 153 & 4.127 & 0.667 & 0.054
\end{tabular}

Source: Field survey 2011.

Table $7 \mathrm{~b}$. One way analysis of variance for significant difference in possible influence to move to urban fringe by different income group

\begin{tabular}{ccccccc}
\hline & Sum of squares & Df & $\begin{array}{c}\text { Mean } \\
\text { Square }\end{array}$ & F-ratio & $\begin{array}{c}\text { Significant } \\
\text { level }\end{array}$ & Remark \\
\hline Between Groups & 6.343 & 2 & 3.171 & 7.764 & 0.001 & Reject $\mathrm{H}_{0}$ \\
Within Groups & 61.272 & 150 & 0.408 & & & \\
Total & 67.615 & 152 & & & & \\
\hline
\end{tabular}

Source: Field survey 2011.

Table 8. Post hoc test for methods comparison

\begin{tabular}{cccccc}
\hline (I)Methods & (J)Methods & Mean difference(I-J) & $\begin{array}{c}\text { Standard } \\
\text { Error }\end{array}$ & $\begin{array}{c}\text { Significant } \\
\text { level }\end{array}$ & Remark \\
\hline Cart pusher & PSP & $-0.754^{*}$ & 0.232 & 0.004 & Sig. \\
& Both & -0.118 & 0.345 & 0.938 & Not Sig. \\
PSP & Cart pusher & $0.754^{*}$ & 0.232 & 0.004 & Sig. \\
& Both & $0.636^{*}$ & 0.266 & 0.048 & Sig. \\
Both & Cart pusher & 0.118 & 0.345 & 0.938 & Not Sig. \\
& PSP & $-0.636^{*}$ & 0.266 & 0.048 & Sig. \\
\hline
\end{tabular}

Source: Field survey 2011.

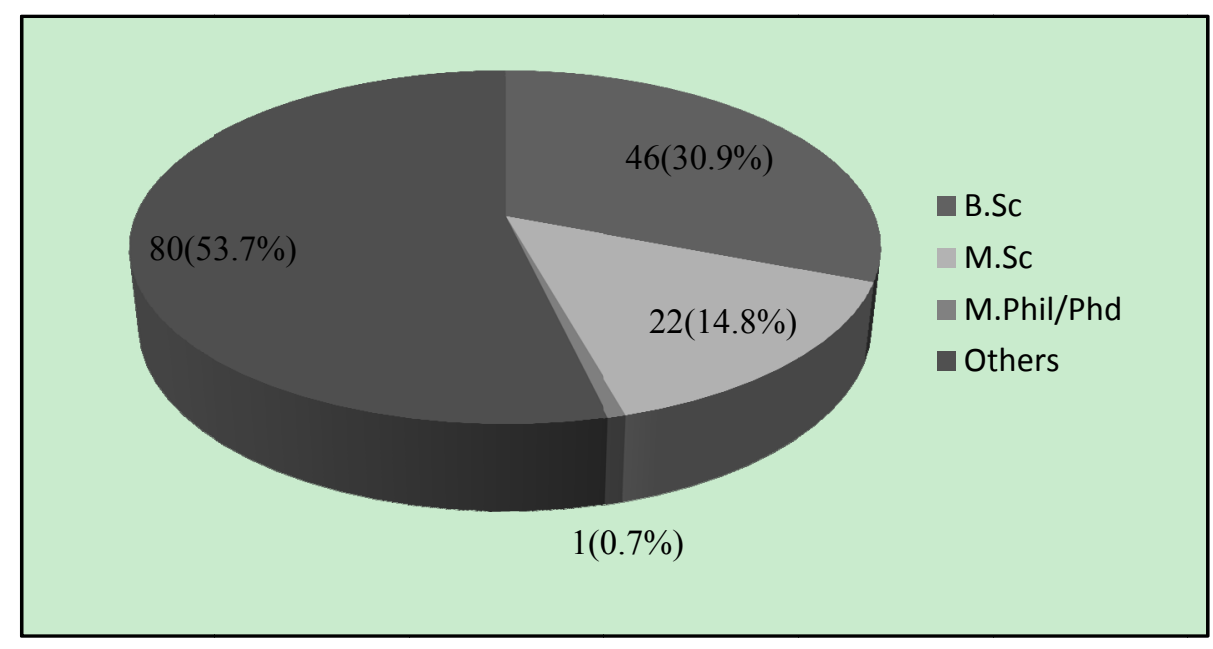

Figure 1. Respondents' highest level of education qualification 


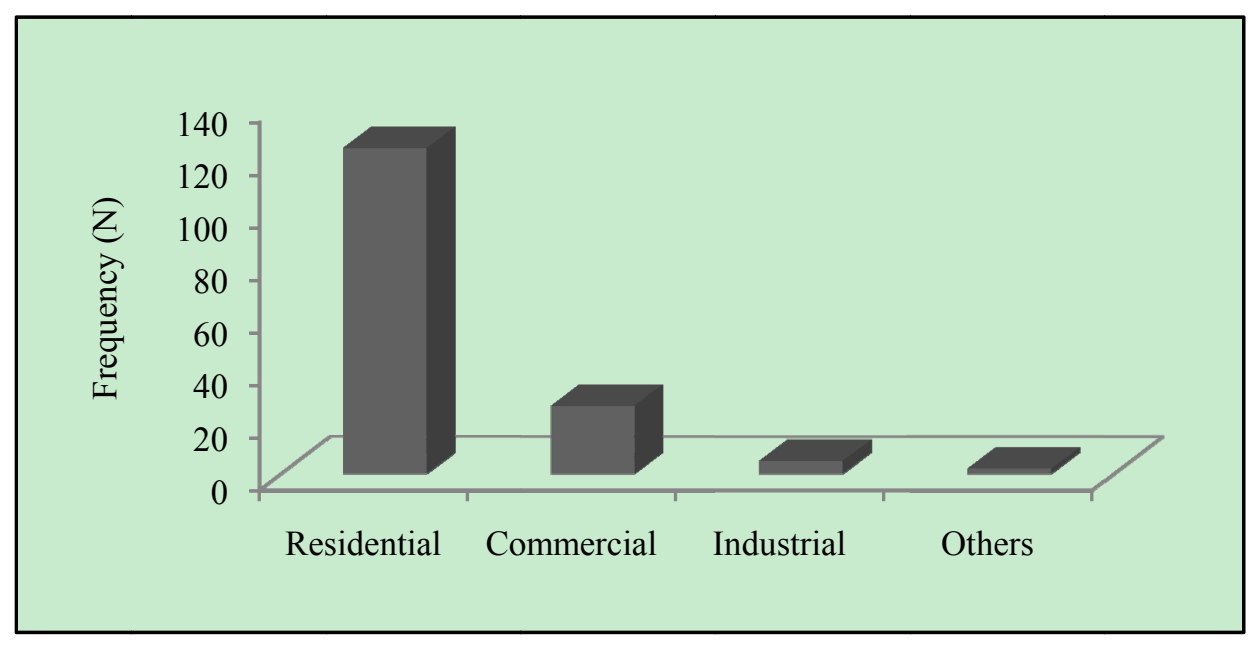

Figure 2. Accomodation types in the area 


\section{Appendix}

\section{Department of Estate Management}

\section{University of Lagos}

Dear Sir/Madam,

questionnaire on outsourcing of solid waste disposal: case study of activities of psp in some selected local government in lagos metropolis.

This questionnaire is designed to collect data on the above subject matter for academic purpose.

Kindly complete the questionnaire to enable us complete the study. All answers provided will be treated with strict confidence and used purely for no other thing but educational purpose.

Thank you for your co -operation.

Yours faithfully,

\section{SECTION A}

1. Name of Respondent (Optional):

2. What is your highest educational qualification?
(a). B.Sc
(b). M.Sc [ ]
(c). M.Phil/Phd
[ ]
(d). Others, Pls. Specify.

3. Property Address/ Location:

4. What type of accommodation do you occupy?
(a). Residential
(b). Commercial
(c). Industrial
(d). Any other [ ]

5. Household Size.

6. How long have you been living in this area
(a). 1-5 years
]
(b). 6-10 years
]
(c). Above 10 years

7. How was your waste disposed in the past?
(a). Cart pusher [ ]
(b). Lawma
[ ]
] (c). Government [ ]
(d).

Carried on head to a public dump in the area

8 . What type of waste do you often generate?
(a). Common Household waste
(b). Commercial and Industrial waste
(c). Others, Pls. Specify.

9. Are you aware of PSP operation in your area?
(a). Yes
]
(b). No

10. When did they begin operation in your area?

11. How do you presently dispose your waste?
(a). Cart pusher
]
(b). PSP [
(c). Both a \& b
(d). Others, pls. Specify

12. Do you know the name of your PSP waste operator
(a). Yes
]
(b). No [
13. Do you know their office address?
(a) Yes (b) No

14. What is the mode of payment for the service rendered by the PSP waste collector
(a). Cash [
(b). Bank [
]
(c). Others, pls specify....

15. Do you support that the service of the PSP waste service provider be retained?
(a). Yes
(b). No
16. Give reason for your answer in 15 . 
17. How often is your waste collected?
(a). Once a week
]
(b). Fortnightly
$\left[\begin{array}{ll}1 & 0\end{array}\right.$
(c). Monthly
[
]
(d).

Any other, pls. Specify

18. When you generate waste do you separate it for before its disposal?
(a). Yes
]
(b). No

SECTION B

Please rate the following likert scale questions as appropriate. $\mathrm{SA}=$ Strongly Agree, $\mathrm{A}=\mathrm{Agree}, \mathrm{U}=\mathrm{Undecided}$, $\mathrm{D}=$ Disagree, $\mathrm{SD}=$ Strongly Disagree

\begin{tabular}{|c|c|c|c|c|c|c|}
\hline & & SA & A & $\mathrm{U}$ & $\mathrm{D}$ & SD \\
\hline 1 & Cost of waste disposal charged by PSP is too high & & & & & \\
\hline 2 & Quality of service provider is excellent & & & & & \\
\hline 3 & $\begin{array}{l}\text { Ubiquitous refuse heaps all over Lagos has now } \\
\text { disappeared }\end{array}$ & & & & & \\
\hline 4 & Attitude of PSP workers is cordial & & & & & \\
\hline 5 & $\begin{array}{c}\text { PSP uses environmentally friendly vehicle-open/ } \\
\text { uncovered vehicle }\end{array}$ & & & & & \\
\hline 6 & PSP'S Vehicle is too old and breaks down constantly & & & & & \\
\hline 7 & $\begin{array}{c}\text { Introduction of PSP has brought environmental } \\
\text { improvement to the area. }\end{array}$ & & & & & \\
\hline 8 & Legal framework establishing PSP is adequate & & & & & \\
\hline 9. & Supervision of PSP operators is adequate & & & & & \\
\hline 10. & Number of times refuse is collected is adequate & & & & & \\
\hline 11 & There is proper record of refuse charge & & & & & \\
\hline
\end{tabular}




\section{Department of Estate Management}

\section{University of Lagos}

Dear Sir/Madam,

QUESTIONNAIRE ON OUTSOURCING OF SOLID WASTE DISPOSAL: CASE STUDY OF ACTIVITIES OF PSP IN SOME SELECTED LOCAL GOVERNMENT IN LAGOS METROPOLIS.

This questionnaire is designed to collect data on the above subject matter for academic purpose.

Kindly complete the questionnaire to enable us complete the study. All answers provided will be treated with strict confidence and used purely for no other thing but educational purpose.

Thank you for your co-operation.

Yours faithfully,

\section{SECTION A}

I . Name of PSP Company:

II . Date of Incorporation

III. Office Address :

IV . Location where you are collecting waste

$\mathrm{V}$. How long have you been in this business.
i. 1-5 yrs
]
ii. 6-10 yrs

[ ]
iii. Above 10 yrs

VI. What is your staff strength.

VII. How will you classify your staff turnover?
i. low
ii. High
]
iii. None

VIII. What type of vehicle do you use for collecting the waste

i. Purpose designed waste vehicle [ ]

ii. Open Van/Lorry [ ] iii. Other type, Pls. Specify.

IX. When did you acquire the vehicle?
i. 1-5 yrs
ii. $6-10 \mathrm{yrs}$
]
iii. Above 10 yrs

$\mathrm{X}$. How do you acquire your vehicle?

i. Through loan from Bank [ ] ii. Equity [ iii. Others, pls specify [ ]

XI.How many vehicle do you have in your fleet?

XII. How many times do you collect refuse per week?

i. Once [ ] ii. Twice [ ] iii. Any other type, please specify

X III. How far is the refuse dump from your area of collection?

i. Within $1-10 \mathrm{kms}[\quad] \quad$ ii. $1-20 \mathrm{~km}[\quad$ iii. $21-40 \mathrm{~km} \quad] \quad$ iv. Above $40 \quad$ [ ]

X IV. How do you charge?

i. Per House/ Accomodation [ ] ii. Per Householder [ ] iii. Others, pls specify.....

$\mathrm{X} \mathrm{V}$. What is your income turnover?
i. Below N100,000
]
ii. Between N100,000 and N200,000
iii. N201,000

\& N400,000

iv. Above N400,000.00

X VI. Has your contract been once terminated by the Government?
i. Yes
]
ii. No
]

XVII. Have you ever stopped carrying the waste at any time since your engagement?
i. Yes
]
ii. No
] 
XVIII. If your answer question XVI is yes, why is this so?

i. Delay in payment of fee by the Government. [ ] ii. Non availability of vehicle due to breakdown. [ ] iii. Other reason, please specify

XIX. Do you separate waste before collecting. ?
i. Yes [
ii. No
]

$\mathrm{XX}$. If your answer in question xix is yes, what method of classification do you use

i Common Household waste [ $\quad] \quad$ ii. Commercial and Industrial waste [ $\quad$ ] iii Both a \& b. [ ] iv. Others, Pls. Specify.

XX I . Where do you dispose waste?

i. Government designated refuse area [ ] ]

ii. Any available bush or valley [ ] ]

iii. Both i and ii [ ] ]

iv. Others, pls. Specify

\section{SECTION B}

Please rate the following likert scale questions as appropriate. $\mathrm{SA}=$ Strongly Agree, $\mathrm{A}=$ Agree, $\mathrm{U}=\mathrm{Undecided}$, $\mathrm{D}=$ Disagree, $\mathrm{SD}=$ Strongly Disagrees

\begin{tabular}{|c|c|c|c|c|c|c|}
\hline & & SA & A & $\mathrm{U}$ & $\mathrm{D}$ & SD \\
\hline 1 & Delay in payment of fee & & & & & \\
\hline 2 & Inadequate enforcement for defaulters & & & & & \\
\hline 3 & Corruption on the part of Government officials & & & & & \\
\hline 4 & Lack of co-operation from the householders that generate refuse & & & & & \\
\hline 5 & Irregular payment by the people & & & & & \\
\hline 6 & People are unwilling to use PSP & & & & & \\
\hline 7 & PSP is forced on the people & & & & & \\
\hline 8 & PSP operators lack inadequate facilities & & & & & \\
\hline 9 & Designated refuse dumps are too far & & & & & \\
\hline 10 & Money paid for the service by Government is too low & & & & & \\
\hline 11 & Awareness of the programme is adequate & & & & & \\
\hline
\end{tabular}

